\title{
QUO VADIS, CIVIL PARTNERSHIP?
}

\author{
Jens M Scherpe*
}

This article discusses and compares the different concepts of civil partnership around the globe: either as functional equivalent to marriage for same-sex couples only or as an alternative to marriage for all couples. It analyses its declining role in the wake of widespread marriage equality reforms and then discusses, in particular, the current position of England and Wales, and Scotland, where ill-conceived law reform has led to a situation in which same-sex couples are privileged and opposite-sex couples are discriminated against.

\section{INTRODUCTION: THE VALUE OF INTERNATIONAL SURVEYS}

At the end of the last century, legislatures in Western jurisdictions began to think about legislation to give two "new phenomena" a family law framework: same-sex relationships and unmarried cohabitation. Neither of the two, of course, was in any sense "new" or a "phenomenon", but what indeed was new was that the time seemed right to recognise these relationships in family law. Before, family was marriage and marriage was family. This fact also explains why these two rather different types of relationships were sometimes dealt with together (see Part III, below). This contribution will look at the development of the formalised regimes that emerged from this, ${ }^{1}$ and the rather curious family law structures that were created, culminating in the absurdity of today's civil partnership law in England and Wales, and Scotland (on which see Part V, below). ${ }^{2}$ It is a classic example of what happens when bureaucrats and politicians ignore the experiences of other jurisdictions and insist on making their own (and avoidable) mistakes.

* University Senior Lecturer and Fellow of Gonville and Caius College, University of Cambridge.

1 De facto relationships or "informal cohabitation", that is, legal regimes that apply irrespective of whether the couple have taken out a formal act/formalised their relationship are beyond the scope of this contribution. But see for example Jens M Scherpe and Nadjma Yassari (eds) Die Rechtsstellung nichtehelicher Lebensgemeinschaften: The Legal Status of Cohabitants (Mohr Siebeck, Tübingen, 2005). For an overview of the registration schemes in Europe, see Ian Curry-Sumner "A patchwork of partnerships: comparative overview of registration schemes in Europe" in Katharina Boele-Woelki and A Fuchs (eds) Legal Recognition of Same-Sex Couples in Europe (Intersentia, Antwerp, 2012) 71; and Ian Curry-Sumner All's well that ends registered? (Intersentia, Antwerp, 2005).

2 In all the United Kingdom's jurisdictions, the formal regime exclusively for same-sex couples is called "civil partnership", although the generic term used, particularly in comparative law, is "registered partnership". 
Bill Atkin has been the general editor of the International Survey of Family Law for many years now, which is incredibly hard and time-consuming work. But it is work well worth doing as it allows the reader to understand developments in other jurisdictions and thus allows for a (better) informed debate. So it is a shame that the Department for Culture, Media and Sport, which was in charge of the recent reforms in England and Wales (discussed in this contribution), apparently did not deem it necessary to consult it. ${ }^{3}$ It is the fate of all great minds that sometimes (and probably more often than not) their work is ignored, but that does not diminish the work. The International Survey of Family Law is only one of the many, many seminal contributions Bill has made to legal scholarship, although arguably it is the one with the most impact globally. This short contribution is dedicated to him, as a scholar and a friend.

\section{IN THE BEGINNING THERE WAS THE NORTH: DIFFERENT BUT EQUAL?}

The first jurisdiction to create a formal legal framework for same-sex couples was Denmark. ${ }^{4}$ In May 1984 the Danish Parliament established a Commission which was to look into proposals ending the discrimination against homosexual men and women, which included exploring the possibility of a legal regime for stable, long-term relationships. While the Final Report of the Commission in 1988 indeed presented a "sketch" of such legislation for a registered partnership in its appendix, this represented the view of the minority in the Commission, as the Commission had in the end voted against such legislation (with six votes to five). Interestingly, the reasoning of the majority was that the couples that most needed protection were the ones who would not opt for a registration of their partnership anyway. ${ }^{5}$ However, despite the Commission not recommending such legislation, most unusually a Bill based on that "sketch" was put forward by Members of Parliament, without much explanation and simply referring to the reasoning presented by the Commission's minority. ${ }^{6}$ Somewhat surprisingly, the Bill was passed by a large majority ${ }^{7}$ and without too much controversy - only the Christian and Conservative parties seriously opposed the

3 Or engage with the decisions of the European Court of Human Rights (ECtHR), or with any other piece of international or comparative scholarship, for that matter.

4 Sweden had created a regime for same-sex de facto couples in 1987, mirroring the one already available for opposite-sex couples. On this, see Hans Ytterberg "'From Society's Point of View, Cohabitation between Two Persons of the Same Sex is a Perfectly Acceptable Form of Family Life': A Swedish Story of Love and Legislation" in Robert Wintemute and Mads Andenæs (eds) Legal Recognition of Same-Sex Partnerships: a Study of National, European and International Law (Hart Publishing, Oxford, 2001) 427.

5 Betankning 1127/1988 at 125 and following. This argument, of course, is still valid when one discusses the regulation of cohabitation/de facto relationships (on which see the references in $\mathrm{n} 1$ above), but was misguided in this context as it "downgrades" all same-sex relationships to cohabitation/de facto relationships.

6 Lovforslag No L 117 and 118 til Lov om registreret partnerskab (22 November 1988).

7 Seventy-one for, 47 against, five abstentions. See Folketingets forhandlinger 1988-1989, column 10840. 
bill. ${ }^{8}$ And thus Denmark had its Registered Partnership Act $1989^{9}$ and was the first country in the world with a formalised regime exclusively for same-sex couples.

In terms of structure and content, the Act has rightly been praised for its elegant simplicity. ${ }^{10}$ The original statute only had five substantive sections, and the approach was to simply state that unless stated otherwise the provisions for married couples would apply to registered partnerships. The exceptions listed in the statute mainly concerned child law provisions (especially parentage and adoption), but over time those exceptions disappeared through various amendments. ${ }^{11}$ This approach also made clear the main aim of the Act, namely to show society's acceptance and indeed approval of same-sex relationships. ${ }^{12}$ Registered partnership was intended to be like marriage in (almost) everything but name, and this approach has become known as the "Nordic Model", ${ }^{13}$ as it was adopted by the other Nordic jurisdictions as well: Norway in $1993,{ }^{14}$ Sweden in $1994,{ }^{15}$ Iceland in $1996^{16}$ and Finland in 2001. ${ }^{17}$

8 For the debate see especially MPs Inger Stilling Pedersen (Kristeligt Folkeparti [KRF]), Folketingets forhandlinger 1988-1989, columns 10473 and following, 10476, 10826 and 10834-10836; Glønberg (KRF), column 10477 and following; Fischer (Konservative Folkeparti), column 10824 and following; Bjørn Elmquist (Venstre), column 10828 and following, and 10831; and Kofod-Svendsen (KRF), column 10837 and following.

9 Lov om registreret partnerskab, Act no 372 of 7 June 1989 (which was amended several times subsequently).

10 Jens M Scherpe "The Nordic Countries in the Vanguard of European Family Law" (2005) 50 Scand Stud L 265.

11 On this, see for example Ingrid Lund-Andersen "The Nordic Countries: Same Direction, Different Speeds" in Katharina Boele-Woelki and Angelika Fuchs (eds) Legal Recognition of Same-Sex Relationships in Europe (Intersentia, Antwerp, 2012) 3; Jens M Scherpe "Zehn Jahre registrierte Partnerschaft in Dänemark Zur Novellierung des Gesetzes von 1989" (2000) 2 DEuFamR 32; and Jens M Scherpe "Erfahrungen mit dem Rechtsinstitut der registrierten Lebenspartnerschaft in Dänemark" (2001) 7 FPR 439. On same-sex couple and children in the Nordic Countries in particular, see Maarit Jänterää-Jareborg "Parenthood for Same-Sex Couples - Scandinavian Developments" in Katharina Boele-Woelki and Angelika Fuchs (eds) Legal Recognition of Same-Sex Relationships in Europe (Intersentia, Antwerp, 2012) 91.

12 See Betcenkning 1127/1988 at 122 and following. This it undoubtedly achieved, see Ingrid Lund-Andersen "The Danish Registered Partnership Act, 1989: Has the Act Meant a Change in Attitudes?" in Robert Wintemute and Mads Andenæs (eds) Legal Recognition of Same-Sex Partnerships: a Study of National, European and International Law (Hart Publishing, Oxford, 2001) 418; and Peter Dopffel and Jens M Scherpe "Gleichgeschlechtliche Lebensgemeinschaften im Recht der nordischen Länder" in Jürgen Basedow and others (eds) Die Rechtsstellung gleichgeschlechtlicher Lebensgemeinschaften (Mohr Siebeck Publishers, Tübingen, 2000) 12.

13 For an overview see Dopffel and Scherpe, above n 12.

14 Lov om registreret partnerskap, Act no 40 of 30 April 1993. For a brief description of the Act, see Peter Lødrup "Registered Partnership in Norway" in Andrew Bainham (ed) The International Survey of Family Law (Martinus Nijhoff, The Hague, 1994) 387. The debates in Norway were much more controversial and the Act only passed by a relatively small margin: 58 for and 40 against in the first chamber, the Odelsting, 
Many other jurisdictions, for example Germany, ${ }^{18}$ Switzerland, ${ }^{19}$ Austria $^{20}$ and the United Kingdom ${ }^{21}$ followed the Nordic approach in principle, ${ }^{22}$ but their statutes lack the simple elegance of the Nordic ones. For political reasons, and to make clear that different really meant different, the enacted statutes which, unlike the ones in the Nordic jurisdictions, do not refer to the provisions concerning marriage and list the few exceptions like the Danish statute but instead explicitly state all provisions that apply to the registered partnerships. As these turned out to be the vast majority of provisions applying to marriage, the new Acts on registered partnerships became extremely bulky and unwieldy. For example, the United Kingdom's Civil Partnership Act 2004 contains some 264

and 18 for and 16 against in the second chamber, the Lagting. Compare with Forhandlinger i Odelstinget 1993 at 451 and 495 and following; and Forhandlinger i Lagtinget 1993 at 36 and following, and 54.

15 Lag $(1994,1117)$ om registrerat partnerskap. The votes in Parliament were 171 for, 141 against, five abstentions and 36 absent.

16 Lög um staðfesta samvist of 12 June 1996 (no 87). For a brief description of the Act, see Davið Pór Björgvinsson "General Principles and Recent Developments in Icelandic Family Law" in Andrew Bainham (ed) The International Survey of Family Law (Martinus Nijhoff, The Hague, 1995) 215.

17 Laki rekisteröidystä parisuhteesta/Lag om registrerat partnerskap no 950 of 28 September 2001.

18 Gesetz über die Eingetragene Lebenspartnerschaft, enacted by the Gesetz zur Beendigung der Diskriminierung gleichgeschlechtlicher Gemeinschaften: Lebenspartnerschaften of 16 February 2001, Bundesgesetzblatt I 2001 at 266 and following of 22 February 2001. For a brief description of the Act in English, see Nina Dethloff "The Registered Partnership Act 2001" in Andrew Bainham (ed) The International Survey of Family Law (Family Law, Bristol, 2002) 171. For a full exposition, see Jens M Scherpe "The Legal Status of Same-sex Relationships in Germany" in Basedow, Kischel and Sieber (eds) German National Reports to the 18th International Congress of Comparative Law (Mohr Siebeck, 2010) 75; and Jens M Scherpe "National Report (on Same-Sex Marriage): Germany, 18th Annual Congress of the International Academy of Comparative Law" (2011) 19 Am UJ Gender Soc Pol'y \& L 151.

19 Bundesgesetz über die eingetragene Partnerschaft gleichgeschlechtlicher Paare (Partnerschaftsgesetz, PartG) of 18 June 2004.

20 Eingetragene Partnerschaft-Gesetz (EPG), BGBL I no 135/2009 of 30 December 2009.

21 The Civil Partnership Act 2004 (UK) applied to all jurisdictions of the United Kingdom. For a brief description of the Act, see Mary Welstead "Reshaping Marriage and the family - The Gender Recognition Act 2004 and the Civil Partnership Act 2004" in Bill Atkin and Fareda Banda (eds) The International Survey of Family Law (Jordans Publishing Ltd, 2007) 185. For a fuller exposition, see Andrea Woelke (ed) Civil Partnership - Law and Practice (The Law Society, London, 2006); Mark Harper and others (eds) Civil Partnership - The New Law (Jordan Publishing, Bristol, 2005); as well as the "official" text by the Women and Equality Unit at the Department for Trade and Industry Civil Partnership: A framework for the legal recognition of same-sex couples (2003).

22 However, the Swiss and Austrian Acts, in particular, differ significantly in many areas from the legislation applicable to marriage. This originally also was the case in Germany, but the differential treatment of marriage and eingetragene Lebensparternschaft applicable to numerous areas was challenged successfully in the German courts and indeed European courts. On this, see Scherpe, above n 18. 
sections plus 30 (often very lengthy and extremely technical) schedules! It also necessitated changing a large number of statutes to include reference to civil partners - a legislative nightmare.

While the enacted statutes differ in technique and, to a certain degree, substantive content, what they all have in common is that they created a legal regime exclusively for same-sex couples and thus a functional equivalent to marriage; a different but (somewhat) equal regime. This gave adult relationship law the following structure in these jurisdictions:

\begin{tabular}{|c|c|}
\hline Opposite sex & Same-sex \\
\hline Marriage & $\begin{array}{c}\text { Registered } \\
\text { partnership }\end{array}$ \\
\hline \multicolumn{2}{|c|}{ Informal cohabitation } \\
\hline \multicolumn{2}{c|}{ Cohabitation without legal } \\
effects
\end{tabular}

\section{TWO BIRDS WITH ONE STONE? REGISTERED PARTNERSHIP FOR ALL COUPLES}

Other jurisdictions took a different approach and created a form of registered partnership which was not only open to same-sex couples but also to opposite-sex couples. Hence for the latter group the new regime was an alternative to marriage. This was, for example, the approach in the Netherlands, ${ }^{23}$ Belgium, ${ }^{24}$ France ${ }^{25}$ and New Zealand. ${ }^{26}$ This then created the following structure for adult relationships:

23 Article 80a-80e of book 1 of the Civil Code, inserted in 1997 (Staatsblad 1997, no 324). See also Frederik Swennen and Sven Eggermont "Same-sex couples in Central Europe: Hop, Step and Jump" in Katharina Boele-Woelki and Angelika Fuchs (eds) Legal Recognition of Same-Sex Relationships in Europe (Intersentia, Antwerp, 2012) 19 especially at 21.

24 Article 1475 and following. Belgian Civil Code, inserted by the Wet tot invoering van de wettelijke samenwoning of 23 November 1998.

25 Article 515-1 and following. French Civil Code, inserted by Law no 99.944 of 15 November 1999. On this, see for example Daniel Borrillo "The pacte civil de solidarité in France" in Robert Wintemute and Mads Andenæs (eds) Legal Recognition of Same-Sex Partnerships: a Study of National, European and International Law (Hart Publishing, Oxford, 2001) 475 especially at 476. On the development leading up to the PACS, see for example Frédérique Ferrand "Die Rechtsstellung gleichgeschlechtlicher Lebensgemeinschaften in Frankreich" in Jürgen Basedow and others (eds) Die Rechtsstellung gleichgeschlechtlicher Lebensgemeinschaften (Mohr Siebeck Publishers, Tübingen, 2000) 113.

26 Civil Union Act 2004. Of course, in New Zealand there already was at that point (and still is) recognition of de facto relationships. 


Opposite sex Same-sex
\begin{tabular}{|c|}
\hline Marriage \\
\hline Registered partnership \\
\hline Informal cohabitation \\
\hline $\begin{array}{c}\text { Cohabitation without legal } \\
\text { effects }\end{array}$ \\
\hline
\end{tabular}

The problem with this approach in terms of potential discrimination is obvious, as in such a system opposite-sex couples have two possibilities to formalise their relationship whereas same-sex couples only have one. Interestingly, while the regimes introduced by the Netherlands and New Zealand essentially afforded the registered partners similar rights and duties as married couples, the regimes introduced in Belgium and France were designed to be different from marriage, with radically different rights and duties attached to the registration. So in the latter jurisdictions the complaint that same-sex couples are discriminated against is a much more substantial one.

Be that as it may, the idea behind this approach is on the one hand to allow same-sex couples to formalise their relationships but also to offer opposite-sex cohabiting couples who do not want to marry an alternative to gain rights (and duties) - and thus to kill two birds with one stone. As has been explained elsewhere, ${ }^{27}$ this approach must be considered a failure if the aim was to provide a legal framework and protection for the ever-increasing number of cohabiting/de facto couples (and their children) as: (a) only a small number of such couples will actually take the step to register; and (b) the couples where at least one of the partners needs protection are the least likely to register. Thus in all these jurisdictions the need to provide protection for couples in informal relationships continued. This is why, for example, New Zealand wisely enacted legislation which covers de facto couples. $^{28}$

27 Joanna Miles "Financial relief between cohabitants on separation: options for European jurisdictions" in Katharina Boele-Woelki and Tone Sverdrup (eds) European Challenges in Contemporary Family Law (Intersentia, Antwerp, 2008) 269; Jens M Scherpe "Rechtsvergleichende Gesamtwürdigung und Empfehlungen zur Rechtsstellung nichtehelicher Lebensgemeinschaften" in Jens M Scherpe and Nadjma Yassari (eds) Die Rechtsstellung nichtehelicher Lebensgemeinschaften - The Legal Status of Cohabitants (Mohr Siebeck, Tübingen, 2005) 571; and Jens M Scherpe "The Legal Status of Cohabitants Requirements for Legal Recognition" in Katharina Boele-Woelki (ed) Common Core and Better Law in European Family Law (Intersentia, Antwerp, 2005) 283.

28 See for example Bill Atkin "The Challenge of Unmarried Cohabitation: The New Zealand Response" (2003) 37 Fam LQ 303; and Bill Atkin "The rights of married and unmarried couples In New Zealand - radical new laws on property and succession” (2003) 15 CFLQ 173. 


\section{THE ADVENT OF SAME-SEX MARRIAGE AND ITS IMPACT ON REGISTERED PARTNERSHIPS}

Interestingly, in none of the jurisdictions described in Part III, does the model outlined still exist, as all of them subsequently opened up marriage to same-sex couples in order to end the differential treatment of these couples. ${ }^{29}$ The same is also true for many (but by no means all) of the jurisdictions described in Part I, above, namely all the Nordic Countries ${ }^{30}$ and also England and Wales, and Scotland. ${ }^{31}$ In all these jurisdictions therefore the question arose as to the fate of the existing scheme of registered partnership. Depending on the starting point, the answers were surprisingly unanimous - with two exceptions (on which see Part V, below).

In those jurisdictions where the registered partnership was designed to be the functional equivalent of marriage for same-sex couples, the opening up of marriage for same-sex couples meant that the functional equivalent had outlived its usefulness. It turned out to merely have been a "stepping stone" 32 on the way to full equality and was deemed not to serve a purpose any more and consequently was abolished when marriage was opened up to same-sex couples thereby creating a three-tier structure for adult relationships:

\begin{tabular}{|c|}
\hline Marriage \\
\hline Informal cohabitation \\
\hline Cohabitation without legal effects \\
\hline
\end{tabular}

Couples living in a registered partnership were given the option to convert their relationship to a marriage, but it was not mandatory to do so. Hence while no new registered partnerships can be entered into in these jurisdictions, registered partnerships will continue to exist for a (finite) period. ${ }^{33}$

29 The Netherlands were the first jurisdiction to do so in 2000 (by amending art 20(1) of book 1 of the Civil Code accordingly; compare Staatsblad 2001, nr 10). Belgium followed in 2003; France and New Zealand in 2013.

30 Norway and Sweden opened up marriage to same-sex couples in 2009, Iceland in 2010 and Denmark in 2012. The Finnish Parliament in 2014 narrowly (105 votes to 92) approved a citizen's initiative to legalise same-sex marriage and legislation is expected to be in place by 2017.

31 In 2013 and 2014 respectively.

32 This term was used, among others, in the Department for Culture, Media and Sport Civil Partnership Review (England and Wales): a consultation (January 2014) at [3.3].

33 Maarit, Jänterä-Jareborg "Sweden: The Same-Sex Marriage Reform with Special Regard to Concerns of Religion" [2010] FamRZ 1505; and Jens M Scherpe "Öffnung der Ehe für gleichgeschlechtliche Paare in Dänemark" [2012] FamRZ 1434. 
For those jurisdictions where the registered partnership regime was open to both opposite-sex and same-sex couples, the logical way to end the differential treatment was to simply open up marriage to same-sex couples while retaining registered partnership in its current form, or in other words just "to fill the gap" in the adult relationship structures. Abolishing registered partnership would, in particular, have deprived opposite-sex couples of an existing and established option to formalise their relationships, which would have been problematic in many ways and extremely difficult to achieve politically. Hence these jurisdictions now effectively have a four-tier system for adult relationships:

\begin{tabular}{|c|}
\hline $\begin{array}{c}\text { Marriage } \\
\text { (both opposite and same-sex couples) }\end{array}$ \\
\hline Registered partnership/formal cohabitation \\
\hline Informal cohabitation \\
\hline Cohabitation without legal effects \\
\hline
\end{tabular}

Therefore it appears that the fate of the existing registered partnership schemes seems to have been dictated by the function each scheme had before the opening up of marriage in the jurisdiction in question and thus the outcomes were rather predictable and logical.

\section{TALES FROM ABSURDISTAN? CIVIL PARTNERSHIP IN ENGLAND AND WALES, AND SCOTLAND, AFTER THE OPENING UP OF MARRIAGE TO SAME-SEX COUPLES}

However, things are different in England and Wales, and Scotland. As described in Part I above, civil partnership in the United Kingdom jurisdictions was created as a functional equivalent of marriage for same-sex couples, with Jacqui Smith, the then-Deputy Minister for Women and Equality, describing it as: ${ }^{34}$

... a parallel but different legal relationship that mirrors as fully as possible the rights and responsibilities enjoyed by those who can marry, and that uses civil marriage as a template for the processes, rights and responsibilities that go with civil partnership.

The express aim was to achieve equality for same-sex couples. ${ }^{35}$ Consequently, members of the judiciary rightly described it as marriage in everything but name. ${ }^{36}$

34 (9 November 2004) 426 UKPD(HC) 776.

35 Women and Equality Unit Civil Partnership: a framework for the legal recognition of same-sex couples (HMSO, June 2003) at [1.1]-[1.2].

36 Sir Mark Potter P in Wilkinson v Kitzinger [2006] EWHC 2022 (Fam), [2007] 1 FLR 295 at 88 ("marriage in all but name"); and Baroness Hale "Homosexual Rights" (2004) 16 CFLQ 125 at 132 ("marriage in almost all but name"). 
So when the Marriage (Same Sex Couples) Act 2013 (UK) ${ }^{37}$ and the Marriage and Civil Partnership (Scotland) Act 2014 (UK) opened up marriage to same-sex couples, ${ }^{38}$ one would have assumed that England and Wales, and Scotland, would have followed the path of the Nordic jurisdictions and abolish civil partnership, thereby maintaining a three-tier structure for adult family relationships. Alternatively, one could also have envisaged a different approach. The legislature could have decided that the time had come for an alternative to marriage for opposite-sex and thus retained civil partnership but opened it to opposite-sex couples as well; this would have created a four-tier structure for adult relationships as described above (in IV.). Surprisingly, England and Wales, and Scotland, did neither and merely opened up marriage to same-sex couples, creating the following structure for adult relationships:

\begin{tabular}{|c|r|}
\hline Opposite sex & Same-sex \\
\hline \multicolumn{2}{|c|}{ Marriage } \\
\hline & $\begin{array}{r}\text { Registered } \\
\text { partnership }\end{array}$ \\
\hline (Informal) cohabitation \\
\hline $\begin{array}{c}\text { Cohabitation without legal } \\
\text { effects }\end{array}$ \\
\hline
\end{tabular}

Hence England and Wales, and Scotland, are now the only jurisdictions in the world which privilege same-sex relationships as these couples now how have two options to formalise their relationships whereas opposite-sex couples only have one. Given that the aim of opening up marriage was to end discrimination and create equality for all couples, this seems a rather absurd outcome - almost as if this had not been thought through properly, which is not that unlikely given the speed with which this not uncontroversial reform was pushed through Parliament. It appears that the Government was so focused on opening up marriage to same-sex couples that it forgot to consider the further implications of reform. However, it at least seems to have occurred to the Government that retaining the current law on civil partnership might be problematic, as s 15 of the Marriage (Same Sex Couples) Act 2013 (UK) states that the Secretary of State must arrange "for the operation and future of the Civil Partnership Act 2004 in England and Wales to be reviewed". ${ }^{39}$ So

37 It is worth noting that it was the Conservative Party who initiated this Act for England and Wales, which is a fairly unique occurrence as it is usually parties left of the middle of the political spectrum that promote legislation for same-sex marriage (or functional equivalents).

38 Which in the eyes of the author of this article certainly was a laudable step!

39 A similar review is under way in Scotland: Review of civil partnership: A consultation by the Scottish Government (September 2015). 
perhaps the strategy was "let us deal with the big problem first and then sort out the smaller ones later"?

If that was the strategy it certainly seems to have backfired. Again, one might be forgiven to see it as a given that such a review would be comprehensive (and maybe even comparative) and would certainly take into account the obvious discrimination and human right issues that the current law raises. Regrettably, this turned out not to be the case. The Department put in charge of the review for England and Wales turned out to be the Department for Culture, Media and Sport (sic!). While there presumably were reasons for this, I think it is fair to say that that Department previously was not necessarily known for its expertise in the area of family law and human rights, and thus seems to be a surprising choice, even to the uninitiated outsider.

The doubts about the expertise of the Department for Culture, Media and Sport unfortunately were confirmed by the work produced. The Consultation Paper has some meagre 20 pages of substantial text (with some generous layout) $;^{40}$ the Report on Conclusions even fewer - some 16 pages of substantive text. ${ }^{41}$ According to the Consultation Paper, the Government's approach to civil partnership has been guided by the following principles: ${ }^{42}$

- $\quad$ Any changes should deliver clear benefits to individuals and society.

- We should avoid taking action that we believe would be detrimental to society or individuals' relationships.

- The fundamental nature of civil partnership as legal recognition of the relationship and public expression of commitment of a loving couple should not be altered, for example to encompass siblings or carers and those they care for.

As Joanna Miles has correctly pointed out, what is apparent is that there is absolutely no mention of principles of equality and non-discrimination, or commitment to these principles. ${ }^{43}$ To make matters worse, the Review Report includes the following statement: "Almost no respondents mentioned benefits other than in terms of advancing equality if civil partnerships were opened up to opposite sex couples." 44

40 Department for Culture, Media and Sport, above n 32.

41 Department for Culture, Media and Sport Civil Partnership Review (England and Wales): Report on Conclusions (July 2014).

42 Department for Culture, Media and Sport, above n 32, at [1.7].

43 Sonia Harris-Short, Joanna Miles and Rob George Family Law: Text, Cases, and Materials (3rd ed, Oxford University Press, Oxford, 2015) at [2.6.1].

44 Department for Culture, Media and Sport, above n 41, at [2.30]. 
Even the casual reader is stunned to hear that "equality" apparently does not only feature as a policy aim, and is dismissed somewhat indifferently as not seeming to be particularly desirable! This is even more inexplicable since this statement is coming from the same Government which opened up marriage to same-sex couples precisely because, in their view, equality and nondiscrimination demanded this. ${ }^{45}$

What is equally striking is the absolute absence of references to the experiences of other jurisdictions, ${ }^{46}$ and the lack of engagement with the relevant jurisprudence of the European Court of Human Rights (ECtHR). There in fact is only one reference to the ECtHR and the European Convention on Human Rights (ECHR), which reads as follows: ${ }^{47}$

We have also learned that the application to the European Court of Human Rights challenging the availability of civil partnership only to same sex couples was declared inadmissible on 12 December 2013.

No further explanation or reference was given, but it is assumed that the Report refers to the application of Ferguson v United Kingdom, ${ }^{48}$ which indeed was declared inadmissible. The reasons for this decision unfortunately are not available to the public. But the application was based on the earlier legal position when marriage was not yet opened up to same-sex couples and hence civil partnership was still the functional equivalent of marriage. The application argued that not allowing same-sex couples to marry and not allowing opposite-sex couples to enter into civil partnership violated the ECHR. Given the Court's decisions in Schalk and Kopf $v$ Austria ${ }^{49}$ and Burden and Burden $v$ United Kingdom, ${ }^{50}$ and the reticence of the ECtHR to interfere with "sensitive matters" such as the national family laws, ${ }^{51}$ it was fairly predictable that such a case would be held to be inadmissible. But with the opening up of marriage, the legal situation, of course, is a completely

45 It is worth noting that, at least currently, there is no obligation to do so under the Convention for the Protection of Human Rights and Fundamental Freedoms 213 UNTS 221 (opened for signature 4 November 1950, entered into force 3 September 1953) [European Convention on Human Rights]. See Schalk and Kopf v Austria (2011) 53 EHRR 19 (Section I, ECHR), noted by Jens M Scherpe "Same-Sex Couples have Family Life" (2010) 69 CLJ 463.

46 Apart from a somewhat random "select bibliography" in Department for Culture, Media and Sport, above n 41, appx A, but none of the listed papers, reports or books seem to have had any impact on the Report.

47 Department for Culture, Media and Sport, above n 41, at [3.1].

48 Ferguson v United Kingdom (8254/11) Application lodged with the Court on 2 February 2011.

49 Schalk and Kopf $v$ Austria, above $\mathrm{n} 45$.

50 Burden and Burden v United Kingdom (2007) 44 EHRR 51 (Grand Chamber, ECHR), noted by Brian Sloan "Adoption, Welfare and the Procreative One-Night Stand" (2008) 67 CLJ 33.

51 The Court generally allows the Contracting States a wide margin of appreciation with regard to the (perhaps questionable but so far still accepted) legitimate aim of "protecting the traditional family". 
different one, and the fact that the previous case was declared inadmissible therefore has very little relevance for the questions the Government actually needed to address.

The ECtHR has consistently held that differential treatment based on sex and/or sexual orientation requires particularly serious reasons to justify. ${ }^{52}$ This means that not only does there have to be a legitimate aim, and the differential treatment of opposite-sex and same-sex couples needs to be necessary in a democratic society and proportionate in reaching that aim, but that there is a heightened standard of justification needed because of the basis of the differential treatment.

However, there is not even an attempt to formulate a legitimate aim for the current law. The Government merely stated in the consultation regarding opening up marriage to same-sex couples that civil partnership is an "established mechanism" 53 for recognising same-sex relationships and that they had been "unable to identify a need" for opening up civil partnership to opposite-sex couples. ${ }^{54}$

As for the first pseudo-argument, as Miles has pointed out, this: $: 55$

... seems particularly odd to suggest that civil partnership should be kept as it is as a means of recognizing same-sex relationships when marriage - hitherto an extremely well-established mechanism for recognizing opposite-sex relationships - has just been opened up to same-sex couples.

As regards the "need" argument, this seems patently absurd in the light of the fact that the Government's own (!) Report seems to suggest that there is a need: namely 20 per cent of unmarried heterosexual respondents to the consultation said that they would rather enter into a civil partnership than marry. ${ }^{56}$ This is further supported by empirical research ${ }^{57}$ (which the Government chose to ignore). Apparently the rejection of marriage by some couples is often ideologically motivated; the persons concerned were not looking for a lesser commitment, but rather a different one which was devoid of the "patriarchal and quasi-religious tenets embedded within even civil marriage". 58 Furthermore, the - admittedly unsuccessful - legal challenge by Ferguson and others. ${ }^{59}$ (of which

52 See only Dudgeon v United Kingdom (1982) 4 EHRR 149 especially at [52]; and Karner v Austria (2003) 38 EHRR 528 (Section I, ECHR) especially at [37], with further references.

53 Government Equalities Office Equal civil marriage: a consultation (March 2012) at [2.19].

54 At $[2.20]$.

55 Harris-Short, Miles and George, above n 43, at 68.

56 Department for Culture, Media and Sport, above n 41, at [2.18]-[2.19].

57 Anne Barlow and Janet Smithson "Legal assumptions, cohabitants' talk and the rocky road to reform" (2010) 22 CFLQ 328 especially at 336-337.

58 At 337

59 Ferguson v United Kingdom, above n 48. 
the Government clearly was aware) as well as more recent challenges, ${ }^{60}$ prove that there is, at least for some, a "need" that the Government felt unable to identify. The fact that this might be a rather small number of people cannot, in itself, serve as an acceptable argument when the issue at stake is one of equality and non-discrimination. The number of "takers" and thus "market considerations" simply do not apply in this context. There is no minimum number threshold that one needs to reach in order to find discrimination.

The questionable approach of the Government to issues of equality and non-discrimination in this area culminates in the final concluding sentence of the Review Report: "Given the lack of consensus on the way forward, the Government will not be making any changes." 61

Notwithstanding the fact that the Government had no difficulties implementing the controversial opening up of marriage to same sex-couples despite there certainly being no consensus on the matter, ${ }^{62}$ dealing with issues of discrimination cannot require a societal consensus. Otherwise a majority could (by simply not agreeing) prevent anti-discrimination legislation. Surely one of the greatest achievements of modern democracy and human rights law is the fact that certain rights, including the right not to be discriminated against, are able to protect vulnerable individuals or groups even if the majority does not agree. Indeed, the whole point of such legislation often is to protect individuals from actions taken by the majority. While admittedly, opposite-sex couples as a group cannot be deemed to be a minority, those who desire a civil partnership (for whatever reason) presumably are such a minority, and as just explained, as a matter of principle, anti-discrimination measures should never have to require a societal consensus.

Hence one is forced to conclude that the Government simply did not do their homework. The math is simple: two options to formalise one's relationships is more than one. Opposite-sex couples have fewer options. That is a differential treatment which needs to be justified. But the Government has not given a legitimate aim for this differential treatment based on sex and/or sexual orientation. The "legitimate aim" of protecting "the traditional family" surely cannot apply here. Not only does civil partnership not have a "tradition" to speak of, it indeed was created precisely because it was a non-traditional way of protecting a (non-traditional) family relationship. So the aim cannot be the protection of the "institution" of same-sex civil partnerships. And now that marriage is open to both opposite-sex and same-sex couples, would it be it threatened by an alternative to marriage (also) for opposite-sex couples? Apparently the institution of marriage which now includes same-sex

60 Owen Bowcott "Couple launch legal challenge against ban on heterosexual civil partnerships The Guardian (United Kingdom, 2 December 2014).

61 Department for Culture, Media and Sport, above n 41, at [3.10].

62 The Consultation (Government Equalities Office, above n 53) yielded the largest number of responses of any consultation process in the history of the United Kingdom, with some 228,000 individual responses (over half of which supported the proposal to allow same-sex couples to marry in a civil ceremony) and 19 petitions against the proposal (between them half a million signatures). 
marriages is not being threatened by the existence of civil partnership. Is the "equal marriage for all" divisible, and one (opposite-sex) needing protection whereas the other (same-sex) does not? Is that the equality that was meant to be achieved? Surely not. Marriage is marriage. As Maria Miller, the then Minister for Women and Equalities said in the debates leading to up to the Marriage (Same Sex Couples) Act 2013 (UK): "Parliament should value people equally in the law, and enabling samesex couples to marry removes the current discrimination and distinction." 63

When stating this she apparently was not conscious of the fact that the Bill she was promoting would create another form of discrimination - this time against opposite-sex couples. But the first part of the statement remains true: Parliament should value people equally in the law. Currently it does not.

\section{WHAT WILL THE FUTURE BRING FOR CIVIL PARTNERSHIP?}

One thing is clear: the law will not stand for long as it currently is. The differential treatment of opposite-sex and same-sex couples cannot be justified, and as mentioned above, ${ }^{64}$ the first legal challenges are on the way. Given the clear dicta of the ECtHR on cases of discrimination because of sex and/or sexual orientation, ${ }^{65}$ one does not need to be clairvoyant to foresee that these challenges ultimately will be successful. Hence, England and Wales, and Scotland, will eventually only have two options: either open up civil partnership to opposite-sex couples or abolish civil partnership. ${ }^{66}$ For both options, as explained above (in Part IV), there are precedents in other jurisdictions. For both there are good reasons. But whatever option is chosen, the decision should be informed not only by the human rights jurisprudence on the matter but also by the experiences in other jurisdictions. One can only hope that (this time) the responsible authorities engage with the international material that is readily available, one of which certainly should be the International Survey of Family Law which Bill Atkin edits so expertly.

63 (5 February 2013) 558 UKPD(HC) 125 per Maria Miller, Minister for Women and Equalities.

64 Bowcott, above n 60.

65 See most recently Vallianatos $v$ Greece (29381/09 and 32684/09) Grand Chamber, ECHR 7 November 2013; and Oliari v Italy (18766/11 and 36060/11) Section II, ECHR 21 July 2015.

66 In Scotland, at least, the Government "is not persuaded that opposite sex civil partnership should be introduced in Scotland": Review of civil partnership: A consultation by the Scottish Government, above $\mathrm{n}$ 39 , at [4.02]. 